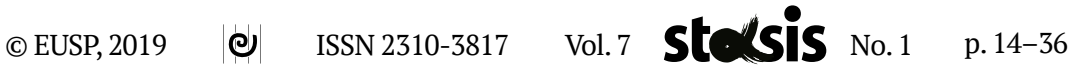

1

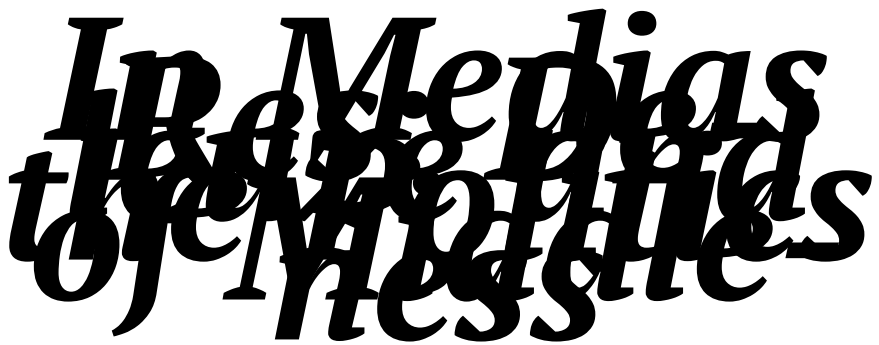

Andrew Pendakis

Associate Professor of Theory and Rhetoric, Brock University

1812 Sir Isaac Brock Way, St. Catharines, ON, Canada L2S 3A1

E-mail:apendakis@brocku.ca

\title{
In Medias Res: Deleuze and the Politics of Middleness
}

\begin{abstract}
This paper explores the links between the work of Gilles Deleuze and two tropes of middleness, both of which are central to the reproduction of neoliberalism. The middle in neoliberal (or postmodern) societies is a tropological constant, first as an explicit political imaginary, what I call the "radical centre" and second, as a background ontology I call "universal middleness". Though this essay does not argue that Deleuze is even remotely a centrist in disguise, it does claim that a worrying resonance exists between too-fast readings of his work and the ambient middles invoked above. When not properly theorized, the givenness of

these ideologies of the middle ends up spontaneously reproducing the common sense of neoliberalism; this is a danger too for those readings of Deleuze that subtract from his work its

radical anti-capitalist core and instead read him as a pure ontologist (of the middle) or as a post-ideological ethicist of the in-between.
\end{abstract}




\section{Keywords}

Deleuze, centrism, middleness, poststructuralism, Marxism, neoliberalism, ideology

\section{Introduction}

This essay explores points of contact between a conjuncture (neoliberalism) and a thinker (Gilles Deleuze). To argue, as I will here, that echoes exist between Deleuze's work and a troubling politics of middleness, a politics roughly coeval with the rise of neoliberalism in the West, is not to suggest that the former is an epiphenomenon of the latter, nor to indict his work as somehow unuseably contaminated by this proximity. Rather, the task is to lay out the contours of a parallelism and to warn of the ways such connections remain available to political forms hostile to the spirit of Deleuze's own work. Slavoj Žižek's critique of Deleuze works along similar lines: it points to a limit or blockage in Deleuze (and his reception) while at the same time finding in Deleuze himself the resources needed to escape it. It is beyond the scope of this paper to lay out comprehensively the conditions linking Deleuze to epistemologies of middleness-such a project, no doubt, would extend far beyond Deleuze himself and expand to include an account of the whole of the French post-Nietzschean tradition. My goal is much less ambitious: to sketch out the coordinates for a broader discussion about the politics of Deleuze in the context of an emphatically "post-political" neoliberalism.

My claim, of course, is not that Deleuze is a vulgar centrist in disguise, but that a troubling resonance occurs between his work-or rather, a possible reception of his work-and a conjuncture, the content of which is politically disastrous. If today's radical center-think here of Emmanuel Macron or Barack Obama-posits capital as the necessary horizon of the possible, Deleuze insists from an anti-fascist and heterodox Marxist angle that we remember all of the exploited, excluded and de-potentiated life at the heart of our moment's order. If the radical centrist rejects revolution as a political category-it prefers its "revolutions" internal to capitalist technological change-Deleuze remains to the end a philosopher of kairos, of that differential time that breaks open the present and sets in motion something radically unexpected, a new people or Earth (whether this openness to the new incudes an openness to revolution in its older Leninist format, however, is a much murkier issue in Deleuze). It nevertheless 
remains that a homology today threatens to appear between Deleuze's work and a certain ideology of middleness visible across a complex array of sites and discourses. This ideology is not in any way homogeneous: rather it is a flexible system of decentralized fragments, memes, habits, and partial objects that enter into relations that are relatively stable despite their intrinsic heterogeneity. In politics, this common sense enjoins us to reject distinctions of Left and Right for a post-ideological consensus grounded in the unmediated production of the new. This brand of political empiricism-a position that conceives of itself as nothing more than constructivist experimentation at the edges of the already known-I call the "radical center." It is important to distinguish this position from a run-of-themill centrism that foregrounds static tropes of moderation, naturalness, or balance: the secret of the radical center is precisely the way it constantly shuttles between stability and chaos, caution and urgency: it understands itself to be at once moderate (rational, careful) and revolutionary (radical, inventive, dangerous) and to be both of these things without contradiction. This formation is in my view the dominant political imaginary of our time, though one that has been thrust into serious crisis by the now impossible-to-ignore contradictions of postmodern capitalism.

Within contemporary culture more generally-meaning popular cinema and music, advertisements, blogs, etc.-a parallel discourse enjoins us to give up on hard and fast distinctions (ideologies, "systems," etc.), on origins and destinations, on all things purposive or rational, and instead to simply enjoy "being in the middle of it all." Be what you are. Let go. Stop letting society define you. The commercials are unambiguous: there is nothing left to do, but be. The goal here is that of drifting apolitically, perhaps seized by a sense of wonder, through the vast connectedness of the One-All. I call this idea, really a kind of folk-wisdom or popular metaphysics, "ontological" or "universal middleness." It is my contention, in line with the political thesis affirmed above, that this is the dominant political ontology of our time, an affect, background logic or ambience that structures much of what passes for experience in late capitalist societies.

Deleuze is strong perfume: it is easy to allow statements cherrypicked from his work to stand in for a carefully reasoned analysis of the whole, just as it is tempting to let the general ambience of the writing to cloud one's sense for the propositional specificity of his positions. It is the atmosphere of Deleuze's work-its incredible, looping repetitiveness; the way it defines terms not all at once, but by using them again and again in different contexts; his tendency to choose concepts with confusing existing resonances that he then quickly repurposes ("transcendental empiricism," for example) - that leaves his texts open to misappropriation by projects diametrically opposed to those envisioned by Deleuze himself. The Israeli Defense Force's use of Deleuzian theory to imagine a nonlinear, "rhizomatic" battle strategy, but also contemporary management 
theory's quick embrace of the assemblage as a form of organization, as well as Silicon Valley's obsession with creative disruption, have led some Left theorists to conclude that Deleuze's work is nothing more than postmodern ideology - the opium of the digital nomad. Though Žižek does not stop here, he makes clear that there is a naïvely affirmative reading of Deleuze that makes him par excellence the ideologist of late capitalism.

It is important to note, however, that if Deleuze is often rejected from the Left as politically contaminated, he is at the same time regularly misread by Deleuzians themselves as a pure metaphysician whose work can be addressed apart from its obvious anticapitalist investments. At work in this position is a tired, old Aristotelian dualism. On the one hand exists theoria, a form of metaphysical inquiry undertaken "for itself," rather than for its consequences or effects. Thought about thought is here elevated and transformed into the grandeur and freedom of pure contemplation (and is modeled in Aristotle as the secret to the self-subsistence of God "himself"). Opposed to this, is a less pure, less "intelligent" thought undertaken in the direction of the production of socially useful ends, ends outside the purview of thought itself. This will come to be framed as the banality of practical reason. At work in this opposition is an ontological aristocratism that pits the leisured activity of the free against the mundane, ends-directed thinking of the busy. We cannot ignore the obvious: metaphysics styled in this register is often resistant to dialectical criticism, not because the latter is "unphilosophical" but because it refuses to honor the claims to sacredness of pure contemplation. When metaphysicians cringe in the presence of a film reference, they do so on the basis of a reflex disciplinary aversion they've never stopped to question: such references (to popular texts) are immediately packaged under the sign of stupidity, or filed into a drawer labeled "mere culture" (a gesture still regularly made by "serious philosophers" in their attempts to trivialize Žižek). For dialectics, however, nothing is uselessly mundane just as nothing is, properly speaking, "extra-philosophical." Rather than propping up these banal field anxieties-of a politics that sees in metaphysics nothing but ideology, of a metaphysics that sees in politics nothing more than gossip-we should instead openly submit to the temptations of the dialectic (a seduction, of course, that is at the same instant always the heaviest of burdens).

\section{Two Figures of the Middle: Between Universal Midle- ness and the Radical Center}

Our moment's incapacity to invent genuinely new forms of politics can be traced, in part, to the cultural authority it grants to a complex ensemble of middles. Two figures are particularly decisive here. The first is a 
gesture primarily made within politics proper, what might be called our moment's dominant political grammar, while the second is a widely distributed cultural pleasure or sensation, a structure of feeling that is at the same time a discourse charged with explicitly ontological pretensions. What links these two forms is their shared reliance on a tropology of the middle or center.

Though they seem to make use of these shared referents in very different (even opposed) ways, they actually end up reproducing very similar models of political practice and possibility. Both conclude that convicted political attachment of any kind-what Alain Badiou calls militancy, but which we might just as well call conviction-is the prerogative of the misled, the blind, and the stupid. Where the first transforms political attachment into the germ of authoritarianism, the latter links it to a lifeless rationalism divorced from the inherent multiplicity of things. In each instance politics - the state, large-scale, long-term economic planning, militant political activity, traditional party forms, etc.-are seen as old, redundant, or in some complex way "false." Interestingly, both frame attempts to represent our moment first, as whole or totality, and second, as a state of emergency in need of urgent political action (for example, on the level of the climate) as misled or naïve: the radical center from the angle of a rationalist (really Burkean) constraint that rejects such gestures as totalizing and anti-empiricist; ontological (or universal) middleness from the angle of an indistinction or fuzziness (and ultimately a nominalism) it sees as prior to the concepts one would need to construct an image of the whole in the first place.

For the radical centrist, ${ }^{1}$ being in-between is a form of knowledge. Left and Right become intellectual dead ends, while the middle is remade as a space of open exchange, complexity and pure experimentation. The middle is here thematized all at once as a) an extra-legal or liminal space (a kind of no-man's land in which anything can happen), b) the neutral habitat of communicative reason (a dialectically charged liberal parliament), and c) a primitive "marketplace" where ideas, desires, and identities exchange in a flat space of ostensibly unhindered possibility (an ancient agora traversed by new conceptions of the world, exotic spices, foreign languages, etc.). The middle is no longer, as it was for Robespierre, a slough or bog ("Le Marais")-a cipher for cowardice, opportunism, and indecision-but the site of an extreme creativity and reasonableness, the purview of "independents," "mavericks," and intelligent "swing voters" (Robespierre 2007:150).

1 For more on the radical center and its relationship to an earlier variant of centrism, please see my "Dialectics of the Swing (Voter): Notes on the Formation of the Radical Centre” (Pendakis 2017). 
Nobel Laureate Paul Samuelson's formulation is here exemplary: "I am not a centrist," he says “because I can't make my mind up about Right and Left, rather it is because each of those has proved itself to be so nonoptimal that rationality and experience move me toward the dynamic moving center"(Samuelson 2008). The old image of the political center as a pragmatic, steady, middle course, as the dull, yet indispensable axis of social order, has been sublated by a center reimagined as a risky space of epistemological invention and possibility, a dynamic zone in which thought transcends old borders and limits. There is a trace of the Aristotelian or Confucian golden mean here, but it is a mean that is not at peace or rest, but capable at the same instant of radical novelty. Todd May argues for the significance of Deleuze's work in the context of a "world that holds banality to be a virtue and originality a disease" (May 2005: 3). As a description of the imaginary of 1950s corporate capitalism and the civil centrism to which it was attached, this would be apt. For the radical centrist, however, operating as they do on the terrain of today's "creative economy," these terms are precisely swapped: originality is now a compulsory cultural norm, while banality, boring self-sameness, is the greatest of sins.

Radical centrists of the Third Way variety tend to be suspicious in principle of the state and instead champion an anarchist horizontalism they associate with the unhindered activity and inventiveness of the free market. Though the radical centrist sees itself as in some very real way "revolutionary," this is a revolution that paradoxically passes through moderation and ultimately the state itself: radical centrist policy targets what it frames as the stupidity and bureaucratic blindness of the state by "opening society up" to the inherent inventiveness of the market. Its own "non-linear" (i.e., "disruptive") and "non-partisan" policy solutions are seen to mirror this inventiveness (which is why so many of these figures come from finance or Silicon Valley). Some of the key thinkers in this Third Way radical centrist movement, of course, were the Labour Party's Tony Blair and the Democratic Party's Bill Clinton, but it should be emphasized that the mobilization of this rhetoric of the extreme or radical center occurs paradoxically across the political spectrum and is as often encountered in the mouth of the (Alt-) Right (Donald Trump, Nicolas Sarkozy, David Cameron) as it is the "the Left" (Bill Clinton, Justin Trudeau, Nick Clegg, etc). What matters is not whether a center discourse is actually "of the middle," but the rhetorical tropes and repetitions it uses to establish itself as such. It is important to note, too, that a position that is in no way politically centrist can authorize itself using classically centrist gestures-Lenin, for example, clearly does not avow a politics of the center (of the kind historically linked to liberalism, for example), but sometimes uses the semiotics of the middle to rhetorically procure consent. Mussolini too often used a rhetoric of the center to secure political intel- 
ligibility and meaning. These centrist gestures or fragments-fragments that can inhabit a whole range of discursive positions-need to be distinguished from a robust self-identification with the center as such.

Alongside this radical center exists a second contemporary discourse in which middleness comes to function very generally as a name for existence understood in the broadest possible sense. I call this "ontological" or "universal middleness." Of course, humans historically have regularly imagined themselves as located at the center of things. Think, for example, of Aristotle's vertical ontology, with Man at an equidistance between God and Mineral or even his cosmological insistence on a fixed Earth located at the center of a series of concentric celestial spheres. Think too of the cartographical hubris of cultures for which spatial centrality was a sign of cosmological election: the most famous example here is of course China, the Mandarin name of which is "Zhongguo" meaning "middle country." What I mean by ontological middleness in its contemporary sense is something very different, an experience or idea that might in fact be characterized as precisely opposed to the avowed centrality mentioned above. Rather than affirming a secure location at the center of Being, ontological middleness captures the perhaps unique modern feeling of being between things in a rootless or purposeless manner. This is a feeling, of course, that finds its paradigmatic expression in the phenomenological ontology of Martin Heidegger. Dasein's fallenness, which locates it spatially as being-alongside as well as its thrownness-its temporal location between past and future - nicely capture the grammatical structure of this singularly modern "being in the middle" - Certainly, there are antecedents here: the Judeo-Christian and Platonic traditions, for example, encode the carnal self as a brief interregnum between birth and an eternal afterlife. Such models, though, operate within highly structured (and ultimately closed) cosmological wholes. Sprawling, messy, existential betweenness-this perhaps, lives best in a city without Gods, or, better, in one where God, finance, infomercials and science nervously cohabit.

The middle, then, is not only a pilgrimage or ascesis oriented toward a destroyed or forgotten balance; it is a word our culture uses to name its vagueness. There is perhaps no better name for the trivial confusion of postmodern space/time than middleness. We might think of this as a secularization of Heideggerian Being, as that which persists when a capitalized (pseudo-religious) Angst is subtracted from modern dislocation and left in the wake of a global whatever. Even if we cannot distinguish the true from the false, the simulation from its referent, even if our categories are miserable and our maps are splotchy at best, there is a profound way in which the shared imbroglio of confusion can be thought today as itself indubitable. As Žižek never ceases to remind us, it is here, under the sign of the apodictic, that we detect the clearest trace of ideological coding. In this highly sophisticated and self-effacing formula, it is nothing more 
than shared doubt-precisely a lack of identity or essence-that binds us together in an ultimate or essential way. We are all, necessarily, in medias res. Where else could one possibly be, but lost, whimsically befuddled, in the middle of it all?

Contemporary film finds this world-picture particularly tempting; think here, for example, of the works of Wes Anderson or Noam Baumbaugh, but also Sofia Coppola or P.T Anderson (especially Punch Drunk Love). If messianic patience is the subjective tone produced by creationist time, universal middleness unfolds in the form of the wait, a waiting without hope or even clarity vis-à-vis the awaited object or event. It is not surprising, then, that our moment's ontologized middleness traffics so commonly in protagonists of slightly stupid sweetness. These are fragile antiheroes-think Michael Cera or Luke Wilson-who learn to abjure striving, not for plentitude or peace, but within an affirmation of shared brokenness and finitude. Failure is here the necessary precondition of the social: we are enjoined to embrace our own idiosyncratic singularity, our wonkily traumatic trajectories, within a cosmos too unwieldy to be grasped by thought. Every Wes Anderson film is a variation on this theme of achieving together one's own failed subjectivity, one's own awkward brokenness, against a background of inscrutable cosmic contingency. "Openness to encounters in an entangled world," what Andrew Culp nicely points to as the slogan of the affirmative Deleuzian mirrors exactly the unspoken political horizon of ontological middleness: exist, wander, connect, repeat (Culp 2016: 10). Everything else is boring system, the meaningless purpose of a life too busy to notice the vital mystery at the heart of things themselves.

These two figures of the middle diverge from and overlap with each other. The radical center tends to be taken up by ambitious neoliberal technocrats, journalists, managers, professionals, or tech entrepreneurs; the ontological middle by slackers, travelers, wanderers, and artists. One promises action, change, transformation; the other a kind of drifting connectedness to things. What links them in both cases is a tropology of the middle resistant to "politics" in the classical sense and to militant (or even consistent) political commitment. Both too have strange resonances with the work of Deleuze, the twentieth century's great philosopher of the intermezzo.

\section{Deleuzian Middleness: Toward a Middle without a Center}

How does Deleuze fit into this doubly charged conjuncture? Like many of his French contemporaries, Deleuze (with Guattari) discovers in the figure of the middle-what he calls "the in-between" (Deleuze and 
Guattari 1987: 380)-materials for the construction of an ontology freed from the limits and aporias of idealism. On some level, the transition from center to middle is characteristic of the whole post-Heideggerian/postNietzschean turn in France. The sudden appearance of a tropology of middleness in the work of figures such as Emmanuel Levinas, Jacques Derrida, Deleuze, Jean-François Lyotard, Michel Foucault, and Maurice Blanchot has remained mostly invisible to commentators because it takes forms that are heterogeneous and that occur at radically different registers and levels (ontological, semiological, metaphorical, social, phenomenological, etc.).Being in the middle, rather than at the center, of course, does not imply necessarily the abandonment of a radical politics of struggle, apolitical form that divides a given situation into friends and enemies and which aims at the progressive transformation of the social totality itself. It doesn't imply this necessarily, but it has nevertheless almost always ended up cryptically de-potentiating and negating this form, even in contexts in which negation as such has been rejected out of hand as excessively dualistic. We should not shy away from insisting that this postHeideggerian tradition, however precious, however necessary, is intrinsically entangled with the forms of thought that made possible this abandonment. This is especially the case insofar as it a) worked to foreground the particular over the universal, singularities over concepts, b) emphasized difference over contradiction, plurality over determinate, antagonizing struggle, c) foregrounded epistemologies of confusion and finitude (blindness, stupidity, error) while de-emphasizing the capacity of humans to know and act in the world (a position that was as axiomatic for Aristotle as it was for Hegel and Marx), and d) called for resistance, deconstruction, or disruption, over organized, purposive, positioned political revolt. Derrida's "hymen" (2004: 223) and "middle voice" (1982: 9), along with all of his gestures to the aporetic or undecidable; Jean Luc Nancy's definition of community "as the appearance of the between as such"(1991: 29); Roland Barthes's concept of the neutral, "everything that baffles paradigm" (2005:6), in addition to the way he regularly styles "being between"(positions, dualisms) as a kind of resistance to ideology; the speed, generally, with which concepts of hybridity, liminality, in-betweenness spread into the fields of architecture, art theory, design, etc., becoming, as if overnight, a kind of unquestionable new postmodern Sittlichkeit: a vast, multimodal cartography would be needed to chart the various ways these concepts all implicitly assume a valorized middleness as the transcendental condition of their intelligibility. Though reality itself in the twentieth century made these positions tempting (and no doubt necessary)-the exhaustion of the party form, the failure of state socialism, the ossification of a certain Marxist-Leninist dogma all played a role herethese middle epistemologies are at the same time modes of knowing that today spontaneously reproduce radical centrist gestures and norms. In 
the wake of the collapse of modern political reason-the logic of the political as such from Rousseau to Mao-such philosophies, despite their real disruptive potential, today play out in very different ways, confirming in advance a postmodern doxa written into the very structure of "things themselves." It would be absurd to ignore the fact that the era in which this middle philosophy presided over the humanities was effectively coeval with the reign within politics in the West of liberal centrism (whether this be of the civil centrist variety-say, from Harold MacMillan to Margaret Thatcher-or its later radical variant, roughly dated between the presidencies of Clinton and Trump).

How does Deleuze fit into this turn? Broadly conceived, the middle for Deleuze is a means by which to reject the shape imposed on time by Platonism. In-betweenness withdraws time from its capture by Being-an order that confines time to the domain of appearances-but also dislodges it from every teleology. Temporally speaking, then, there has only ever been and only ever will be middleness (or difference and repetition): nothing in the collapse of our universe would change this (it would only be another pleat for Deleuze in the ongoing material adventure of univocity, Being/becoming here envisioned via Gottfried Wilhelm Leibniz as infinitely folded difference). Middleness, then, is the name given to a posttheist time without beginning or end, but also to a space that is simultaneously always at once center and periphery. "One never commences," says Deleuze, "one never has a tabula rasa; one slips in, enters in the middle; one takes up or lays down rhythms" (1998: 123). Deleuze explicitly frames the rhizome as well as singularities themselves as constitutively of or in the middle. "A rhizome," he and Guattari write in A Thousand Plateaus, "has no beginning or end; it is always in the middle, between things, interbeing, intermezzo" (Deleuze and Guattari 1987: 25). Later in the same text he says of the haecceity that it has "neither beginning or end, origin or destination; it is always in the middle" (Deleuze and Guattari 1987: 263). Craig Lundy, in History and Becoming: Deleuze's Philosophy of Creativity, writes that "in the final analysis it is always a "middle ethic" and ontology that Deluze and Guattari aspire towards": "it is in the middle realm-in the midst-where everything happens" (Lundy 2012: 97). To begin, then, it is important to note the double nature of this middleness, one that constantly oscillates (sometimes imperceptibly) between ontology and ethics: it is at once a metaphysical postulate about the nature of Being/becoming, a way of describing things as they always already are and an ethic, a norm, a way of inducing something (a mode, a thought, a practice) that does not yet exist. This is of course precisely the two-sidedness of the rhizome, an arrangement that exists around us operating in every possible direction and on an infinity of scales and a procedure or set of relations that needs to be desirously made and remade. 
It is important to distinguish the middle put to use by Deleuze from the cultural associations set to work by the concept of a center. Deleuzian middleness is certainly not a mid-point, the kind of middle we associate with the center of a line, for example: a haecceity is not "made of points, only of lines" (Deleuze and Guattari, 1987: 263). Mid-points conceived as spatial coordinates are flat and linear: plotted onto a static line they are figures of geometrical balance and exactitude. For Deleuze, the middle is too experientially textured, too mobile, and too charged with uncertainty and experimentation to be rendered in the language of a static point. Moreover, conceived of as dimensions in time, mid-points necessarily become breathing spaces between an origin and a goal. In other words, points are bourgeois psychologies, forms of movement on the way to destinations already known in advance. The trope of the nomad is mobilized by Deleuze precisely to undercut the domination of time by a logic of destinations: "A path is always between two points, but the in-between has taken on all the consistency and enjoys both an autonomy and a direction of its own. The life of the nomad is the intermezzo." (Deleuze and Guattari 1987: 1987).

The middle, for Deleuze, is to some extent a name for the plane of immanence itself, for the "material universe" understood as a whole, a univocity without limits in any direction or fixed on any specific scale (Deleuze 1986: 59). There is a certain ambiguity around this concept in Deleuze's work, one that has to do with whether it is preceded by an indefinite or definite article: it is possible to conclude that for Deleuze, planes of immanence exist only in the plural and that there are as many of them as there are Nietzschean "interpretations"; this would properly speaking not be a relativism (which Deleuze always rejects), but a perspectivism that leaves room open for an infinity of worlds, dimensions, etc. The middle in this reading would not just be the necessary location of anything that exists-that is, the world taken as an undisclosable or infinite whole-but the space between "worlds" themselves (say between dimensions in speculative physics or, more prosaically, that between the world of the tick, say, and that of the crystal). Either way, universal middleness replaces the vertical ontologies of the Platonic and Aristotelian systems with flat, horizontal lines that no longer exist under the erasure of transcendent, supersensible essences or ideals. But the middle is not simply an inversion of idealism, it is a critical gesture undertaken within materialist immanence itself. Framed by Deleuze as a kind of speed (and in this sense resembling the infinite speed he links to both chaos and acts of creation), the middle is at the same instant an epistemological figure, a zone of confusion-a kind of "fog" (Deleuze and Guattari 1987: 263)where the clear lines between things blur and in which it becomes possible, away from opinion and inherited common sense, to produce something new. Deleuze's "transcendental empiricism" is here directly at odds 
with its seventeenth- and eighteenth-century antecedents: for thinkers such as John Locke, empiricism was a bourgeois science that aimed at the consolidation of identities and at clarifying or simplifying the relationship between words, ideas, and things; the right word and concept was to be attached to a systematically explored physical phenomenon with the result being usable, stable, communicable knowledge. Deleuze's empiricism does not take as its object a definitive description of reality that terminates in convenient, consensual knowledge; it operates instead at the border zones of "experience" and between "things" insofar as no thing (properly speaking) exists in the first place. A commitment to middleness is in this sense a commitment to the fuzzy borders between and "under" every stable identity: it is a theory and practice of non-identity.

Deleuze's transcendental empiricism "takes place" in the middle. This middle, however, is not a phenomenologically stable amidst we link to the consensually established space-time of everyday perception. It is, rather, a simultaneously exhilarating and terrifying space of speed and change. As an ethos, the middle is a way of relating to things beyond the logics of identity and representation, a form of radical creativity, as well as a fundamental openness to "differences" (be they social or ontological). There is, for Deleuze, something "uncomfortable" about the middle, a difficulty or strangeness proper to the in-between (Deleuze and Parnet 2006: 29). An ethics of the middle, then, exists in opposition to the ostensibly "fascist" logics of what Deleuze and Guattari call "paranoic" molar groupings, forms of collectivity-such as the orthodox Left and Right political parties they target-that substitute sovereignty, self-sameness, and totalizing programs for a more open, flexible, and difference-oriented approach to politics.

\section{Middleness and Post-Ideological Thought}

If there is a centrism in Deleuze, or rather, a usefulness to centrists, it does not lie in some untheorized, subterranean center thought to structure his work unconsciously from within. As with Derrida, Foucault, Louis Althusser, and other writers in France in the '60s and '70s, Deleuze rejects emphatically the intrusion into philosophy of centers imbued with transcendental or structural necessity. Cosmologically, this means rejecting the Aristotelian-Ptolemaic image of an unmoving Earth located at the center of a revolving system of concentric celestial spheres and with it the very idea of a bounded universe structured around a fixed point of any kind. "Psychologically," this means disarticulating the subject from any link to a transcendent soul, ego, personality, or self: the subject, as it were, exists alongside the body's crowd as an effect or product, the "whole" a 
mere part or piece among other parts and pieces. A similar gesture is undertaken in the space of the political. For Deleuze, there has never been nor could there ever be a society organized around a fixed point: instead, when this comes to appear the case-in despotic regimes, for examplethe complex assemblage of desiring machines that actually animates and sustains an order has been covered over and de-potentiated by the resplendent fiction/abstract machine of absolute sovereignty. Deleuze, in other words, is unsparing in his critique of what we might call the metaphysical (basically Aristotelian) center, a center the basic organizing principle of which echoes throughout the dominant psychological, ontological, and political imaginaries of the West.

At the same time, Deleuze unequivocally rejects the political content of the (radical) center, especially its attempt to transform "extreme" moderation into a kind of unsparing rationalism: "It is up to us," he writes, "to go to extreme places... not [the] temperate zones [of the] moral, methodical, or moderate man" (Deleuze 2006: 110). Moreover, Deleuze has nothing but scorn for the radical center's technocratic and specialist leanings (often couched in the language of a mathematized finance); sees as naïve the idea that technological innovation will seamlessly terminate in a more just or free society; is highly critical of both liberal democracy and communicative reason; and rejects outright the free-market orthodoxy which undergirds the radical center's suspicion of the state.

If there is a point of direct intersection between the radical center and Deleuze's own work, it lies in the form of a grammar, one connected to the role played by the concept of ideology in Deleuze's work. Deleuze, of course, rejects ideology as a category on the basis of its reliance on an opposition between essence and appearance he claims was contracted through Plato and passed into Marxism via Hegel. To frame the world as subsumed by ideology is, for Deleuze, to sink its difference in abstract sameness: it is to take the differential multiplicity of things as they are and might be and reduce them to the gray half-life of an epiphenomenon. At the extreme outer limit of this reduction is the kind of intellectualist spectatorship one finds in late Adorno: the task is no longer to employ thought to actively change or transform the world, but to interminably map the damage done to life (and thought itself) by capital. For Deleuze, the idea of a complete subsumption of the virtual by ideology leaves the individual and its force, but also the very possibility of a new world, erased under the sign of total falseness. The latter, from Deleuze's perspective, looks very much like a variation on Augustinian pessimism in which the world is reduced to a dark vale of tears, suffering, failure, loss, and so on. In other words, it looks like life-denying nihilism.

If, however, Deleuze rejects the efficacy of ideology as a category for thought, he nevertheless has nothing but disdain for the habits of mind conventionally linked to ideological thinking. The latter, charged with a 


\section{For Deleuze}

desire for sovereignty and characterized by dangerously paranoic either/or binary logic intersperses itself between a subject and its own force, between a brain and its own virtual infinity. It has an affinity with what Deleuze calls "opinion" and that he frames as a kind of umbrella of values set up to keep at bay the chaos which genuine thought constantly threatens to reintroduce into experience (Deleuze and Guattari 1994: 202). For a world divided into absolute Lefts and Rights, Deleuze substitutes the adventure and uncertainty of middleness, that zone in which genuine ontological and political experimentation actually takes place: "It's not easy to see things in the middle, rather than looking down on them from above or up at them from below, or from left to right or right to left: try it you'll see that everything changes" (Deleuze and Guattari1987: 23). The middle, for Deleuze, is difficult, rare, and intrinsically transformative; the poles, meanwhile, are easy, common, and do nothing but reproduce what already exists. What is fascinating is that Deleuze's injunction to "go to extreme places" is precisely tailored to avoid the "extremes" of the traditional political spectrum (Deleuze 2006: 110). It is instead an injunction to the middle, to an extremity taken as intrinsic to middleness itself: "the only way to get outside the dualisms is to be-between, to pass between, the intermezzo" (Deleuze and Guattari 1987: 277).

The radical center operates on a disturbingly similar set of terms, gestures, and relations. Truth it frames as the illusory prerogative of dualism, the error of a world violently reduced to either/or. As in Nietzsche and Spinoza, fear is the mother of Truth; subjects cling to dogma-abstractions such as "equality" or "communism," for example-out of confusion and obscure wills to power that remain beyond the scope of their reckoning. Fascism becomes the subjective comportment of every consistently avowed program or political plan: what binds Left and Right beyond the appearance of difference is the irrational, tribalist intensity with which they pursue values located outside of rather than within the world. This attempt to conflate the difference between the poles, between the terms that call into being the center as such, is one of the strongest indicators of radical centrist discourse. Ideological systems it sees as clouds of sclerotic values, old ideas that have hardened into dogmas and which now interpose themselves between the subjects and their capacity to encounter or respond to the real. Remember, too, that the real here is not just "reality"-empiricist, ready to hand, formed in advance-but something closer to the virtual itself: reality, in other words, is for losers and followers, for minds too docile to radically re-make it. On the other side of ideology the radical centrist poses the risky, uncertain, and interminable process of the experiment, one it always sees as happening in medias res: one either discriminately picks and chooses elements from the poles (a kind of tasteful bricolage of positions) or inhabits the middle as a space of intense productivity entirely beyond the terms laid down by the traditional 
political spectrum (inventing something that has never been seen before). In other words, what the radical center calls for is outright Nietzschean transvaluation (albeit within the fundamental politico-economic coordinates of liberalism): it sees its own practice as the bearer of a creative destruction that does away with the old even as it engenders a new "beyond good and evil" (hence its interest in amoral, "naughty" agents who stand apart from customary norms and whose distance from moralism is repackaged as hostility to convention tout court).

The point that should be stressed here is not really that Deleuze's discourse mirrors that of the radical centrist on the level of content, but rather that his work enters into a certain parallelism with it on the level of form. In each case the critique of ideology and of ideological thinking culminates in a position that is openly ontological: an arc is traced from mystification to Being/becoming, from illusion to things as they really are (even if this "things as they really are" is simply appearances all the way down). What is interesting is how this gesture to the real is preceded in both cases by a kind of ritual epistemological humility. Truth assembles not in the form of dogma or certitude, but as an openness to newness, an encounter grounded in the surprise of the foray: a homology then opens up between this comportment and a "difference in itself" that actually (or virtually) composes the metaphysics of the real (Deleuze 1994: 55). Paradoxically, the illusion that is dispensed with once we exit the terrain of ideological thinking (and the very concept of ideology) is Truth itself, Truth in the form of a conclusion: "the idea of another world, of a supersensible world in all its forms (God, essence, the good, truth)[...]is not one example among many but the constitutive element of all fiction" (Deleuze 2006: 147). Deleuze's metaphysical claims, however, are truths in the plural, truths posed singularly on the terrain of a specific ontological stratum or dimension and "absolute" in the space in which they transpire: they are not in this sense mere "truth-claims," a vocabulary proper to the Anglo tradition and foreign to Deleuze's critique of representation. Instead, they are products of an experimentation that paradoxically possesses truth only insofar as it resists terminating its process in a result. Deleuze's entire project is in some sense little more than a record of (and injunction to) experiments: they are traces left by experiments, or better the experiments themselves. Add to all of this Deleuze's core tropological obsessions-machines, bodies, bodies in various states of collapse or explosion, flows of sperm and shit-and what one gets is a text charged with a remarkable aura of unmediated materialist Truth. One is thrust into a world of things that work, buzz, collide, and fail, an enormous buzzing amidst, the machines and flows of which Deleuze again and again insists are not metaphors: it is hard not to feel like one is suddenly in the presence of materialist Being itself freed from the bulky mediating presence of every ideology and system. This effect is intensified by the way shit and sperm 
trade like rebellious contraband after the long, bodiless "No" of idealism: one comes to feel that here, finally, is immanence, things as they are in all their redolent sensual stench and color. To have done, once and for all, with bourgeois fairytales and moralisms: Deleuze's desire to provokeone he frames as a project of defamiliarization to aggressively interrupt extant habits of the mind and body-is in fact rhetorically incorporative and here works to deepen the impression of a materialist reality finally encountered in all its messy truth. Provocation is a rhetorically suspect alibi: so often what is in fact the mechanism for a whole, encoded politico-metaphysics is allowed to pass as nothing more than an open desire for newness or difference-the innocence of a new way of seeing. In short, Deleuze's work is powerfully set up to produce an almost irrefutable kind of consent. Foucault's own response to Anti-Oedipus-in which he claims that the text is effectively post-rhetorical (with rhetoric here linked to manipulation and an explicit desire to convince)-is here utterly symptomatic (Deleuze and Guattari 1983: xiv).

We have to be very careful here. Certainly, the world is actually filled with shit and sperm, machines, both desiring and abstract: there is a very real way in which Deleuze's ontology is among the most comprehensive and convincing of the century. Are we not, in fact, ontologically, "in-between" in precisely the way described by Deleuze? The problem here is not with Deleuze's ontological realism per se, but with the dialectical usages of its "reality effect." One of the most absurd recent trends within realist interpretations of Deleuze, Manual DeLanda's for example (2008), has been the representation of dialectics, (but also discourse analysis and Cultural Studies) as inherently idealist, a crypto-Kantianism that imagines it as irrevocably separated from the world of things themselves and trapped, as it were, behind a screen of concepts and words. On this account, dialectics is a hyperbolized Lockean epistemology through which we never actually encounter things themselves but rather only the ideas we have of them. The tradition of thought stretching from Adorno to Jameson-one we might call dialectical materialist-however, at no point denies the materiality of being, nor the mind-independence of the world. Though there may be outliers within Cultural Studies, for example, who adopt this position, the notion that dialectical materialist criticism or discourse analysis is idealist is absurd. What dialectics insists on, within a bluntly mind-independent world, is our constant location in fields of meaning that regulate our sense of the possible and which have the capacity to distort or expropriate our speech acts in ways that can never be anticipated in advance and along lines laid down by the limits of our moment's political unconscious.

The problem with Deleuze's auratic materialist Truth is not the claim it makes to a hold on things as they actually are, but in the way this claim imperceptibly morphs into a set of ethical and political norms; the way, 
that is, that an image of Being shades into a corollary image of an ideal way of being political. Here we must be totally clear: there is no necessary connection between an ontology and a politics, no political form that can be said to "match" or "properly" reflect Being itself. Having a "correct" ontology in no way implies an effective or interesting politics just as a "correct" or effective political sequence in no way presupposes access to metaphysical truth (the fascinating political trajectories of liberation theology are themselves sufficient evidence here). It is in the easy slippage between a convincing ontology and an injunction to a certain way of doing politicsin Deleuze's case, a politics that is anti-statist, suspicious of political plans and programs, and grounded in a very particular conception of the desiring subject-that the problems appear. We can go further: to be in possession of a true image of Being/becoming-in our case the ontological middleness described by Deleuze-in no way ensures that this image will not function as a barrier to inventing the kinds of political positions needed by a time, the kinds of politics required by a planet that faces problems on scales never before experienced by human beings (climate change, globalized financial events, loss of biodiversity, etc.). It is in this sense that an ontology can be true and false at the same time: if the angling of this "reality" interrupts the capacity of a people to invent the political forms adequate to a time's worst nightmares, it has displaced and even retarded that axis of the "Real" which pertains to the autonomous, self-regulating logics of the political.

Dialectical criticism attends so closely to the mechanisms of framing, to "rhetoric," not because it thinks that nothing exists outside the latter, but because it sees in every speech act the risk of capture by an enemy. Speech acts fail immanently-which is to say, on their termswhen they are captured by a rival. The availability of Deleuze's work to capture by a radical centrist imaginary at odds with his own emphatically anticapitalist position is not speculative or hypothetical: it is fully visible within the scholarly reception of his work. DeLanda is here symptomatic. When someone like DeLanda writes, he does so in the unobtrusive language of an expositor of things so obvious they almost need not be mentioned. His enunciation is that of the kindly uncle whose patient explication has only your best interest in mind. He peppers his writings with examples taken from the natural sciences or mathematics or from everyday contexts that slowly construct an impression of irrefutable common sense. There is certainly something admirable in this clarity. However, it is in the transition from the ontological to the political that DeLanda's project badly misfires. His commitment to a certain kind of Deleuzian empiricism takes him very close to a species of political nominalism-one shared by the radical center-in which concepts such as “capitalism' are rejected as too general, aspecific, and ideological to be useful. Such universals for DeLanda are fetish objects and we know this via the way he explicitly frames Marx, in a stale joke, as little more than 


\section{For Deleuze}

Deleuze's bad Oedipal Daddy (DeLanda 2008: 176). This image of Marx the Father, a bearded and stern Marx who stands over Deleuze in the form of an unconscious attachment/blockage, channels all of the usual radical centrist platitudes linking Marxism to paternalism, dogma, and violence. Marx is a father in precisely the same way capitalism is a concept: both mystify the source of their own authority, both punish difference from the vantage point of a false universality. In a remarkable act of sophistry, Deleuze's insistence on the need to overcome the Father of Capital-the fake sovereignty of Capital-is transformed into a rejection of the Father asleep in the very concept of capitalism itself. The solution is clear: universals such as capitalism need to be overcome in the same way we need to have done, once and for all, with all of the Fathers that continue to haunt, constrict, and impede our desire. Rejection of anticapitalist critique is here performed in a key of riot: Marxism reborn as gray fatherhood falls prey to a muscle memory of repression as old as childhood itself. The only thing more foolish than digging these old socialist trenches are trenches themselves, the banality of all fruitless digging, and of anything done over and over again without chance of success or pleasure. In the corpse of the Father lies all of the world's richness, multiplicity, and difference, a politics freed once and for all from the specter of authority.

We are not surprised, then, to learn that the political scale appropriate to a molecular, machinic ontology is one that begins in the specificity of the local, rather than at the "vague generality" of a planetary capitalist system (DeLanda 2008: 176). This is what DeLanda means when he ends his essay with a bizarre injunction to adjust our politics to the "right social scale" (DeLanda 2008: 177). Though DeLanda may not believe in ideology, his work is the purest example of the way ambient ideological scraps and fragments get into the content of an idea in the same way toxins do the skin and hair of our bodies in the street. DeLanda's taste for the molecular, his radical centrist suspicion of the state, political fidelity, and Marxist abstraction leads him to ignore the fact that in Deleuze there is no "right scale" for a politics, just as there is no "right scale" on which to generate an ontology. Deleuze is excruciatingly clear about this: it is wholly possible to envision revolutionary transformation, a new Earth or socius, on the condition that the existence of the latter does not extinguish, abolish, or render as subordinate the desiring-production on which it relies for its existence. For anyone who understands the nature of today's most pressing political problems - a financial system the instability of which has been fully globalized, an extractivist capitalism that threatens many of the natural systems humans and animals need to stay alivethe notion that what we need now is a politics adapted to the "proper" scale of the local is absurd. As Deleuze himself teaches us, the planet itself is a tiny pleat in the great ramifying complexity of Being: to call a political thought that aims at the planetary totality "too big" is just as absurd as 
ending the search for new forms of complexity at the seemingly primary "smallness" of the atom.

\section{Conclusion: From the Middle to the End}

It would be too easy and simply incorrect to conflate Deleuze's attachment to the middle with the two figures of middleness that I have described above. My concern lies not so much in the content of Deleuze's ontology, but with the way the latter often quietly shades into an injunction to a particular style of politics. An ontology grounded in differential middleness combined with an ethics fused to the idea of virtuous middle passage risks inadvertently reinforcing our moment's capture by radical centrist norms and habits: things themselves will always be too fuzzy to be totalized, too plural to be organized under the sign of a universal (even a concrete universal like capital), just as being-in-between-whether it be between parties, between perspectives, or even between affects-will always be valorized over the determinacy of an emphatic political position. This resonance, however, only sets in if one extracts from Deleuze the anticapitalist political investments that subtend his commitments to newness, becoming, and change. Having done so, it is not impossible to transform Deleuze into a sophisticated metaphysical accomplice of the worst contemporary platitudes. "Truth is somewhere in the middle"; "It's the journey not the destination that counts"; "Forget the future, live in the Now": how many conversations have ended in these abysmal clichés, bad metaphysics dressed up as unchallengeable common sense?

An open question remains, however, as to whether or not Deleuze's subject on its own terms is capable of generating the kind of systemic political change his work as a whole posits as necessary. Claire Colebrook writes that "Deleuze's entire oeuvre is dominated by a desire to think singularities[...]not the organized, managed, synthesized wholes which allow us to act efficiently and continue being ourselves" (2006: 28). Is a subject so closely tethered to the production of the new, so emphatically averse to self-sameness, a sustainable or even effective political agent? It may be that politics in a radical modern key, one that produces consistent strategies aimed at concrete, appreciable effects, requires a kind of self-limiting tenacity, a purposive endurance and even an openness to boredom that looks very little like rhizomatic intensity. What kind of subject is needed to endure again and again political encounters without glory or newness, contexts that require nothing more than an almost quantitative, arithmetical stamina? What happens if cultivating a tired old territory, digging a trench, is precisely the precondition for the creation of a society that genuinely institutionalizes difference and innovation (rather than paying both a merely token respect)? What if letting a territory ossify into knowl- 
edge and routine-even the givenness of opinion-were the only useful weapon against a capitalism that leaves nothing ever the same and which uses non-conformity as a mechanism of obedience? What if we can only get to difference-to a society that unleashes becoming - by founding it in the shimmering purposiveness of Law? Which is to say: What if being in the middle ontologically could only happen by orienting ourselves to Ends and to an ends-directed thinking that precisely places to the side the lustrous immanence of "being in the middle" of it all?" It may be that the "organized, managed, synthesized wholes" that "allow us to act efficiently" and to "continue being ourselves" are not simply the condition of the reproduction of the status quo, but the condition of its abolition as well (Colebrook 2006: 28).

From an orientation to newness to the capacity to endure an unremitting sameness: this is perhaps simply a case of replacing one cast of political heroes-the nomad, the schizo, the vanguard artist-with another. This power to endure might take the shape of Badiouian fidelity, but it may also be a more mundane figure than his dice-rolling militant. Or perhaps the militant as a model works on the condition that it is envisioned taking notes at its tenth meeting of the day rather than immortalized neo-classically on the barricades. This is precisely the direction indicated by Jodi Dean's (2016) invocation of the comrade, a depersonalized political agent that is no less ungrounded than the nomad, no less internally divided, but which is nevertheless powered from within by the externality of a collective, contingent, and in some ways mundane End. Perhaps, what we need today looks less like a nomad and more like a revolutionary bureaucrat. This would be a strange figure of repetition without newness, a figure of endurance designed to pass through the mundane without losing hope or dangerously internalizing its distance from the Herculean militancies of old. ${ }^{3}$ Politics, we could say, is gray labor and never more so than in the dead time that antedates a genuinely revolutionary period: however much dancing we try to cram into our politics there will always re-appear at its edge the bare cubicle of intentional duration, a time of quantitative adding. Arguing over coffee again and again; the flat-

2 This is not, of course, the substitution of the aprioristic for the thickly experiential: Marxist-Leninism, to take just one example, for all the attempts made by enemies to transform it into an idealist eschatology, was always an experiential science of the conjuncture, a testing out of the lines of force and resistance of strata, a playing on the edges of the difference between what exists and what might. In this sense there is not a huge difference between the Marxist-Leninist and Rochau's Realpolitik: both operate on the inside of what already exists, constantly redefining goals on the basis of a reading of the conjuncture.

I have written about the continued significance, but also the limits of $\mathrm{Ba}$ diou's conception of the militant as it pertains to communist strategy elsewhere (Pendakis 2014). 
tened, maddening temporality of the thread war; the banal labor of handing out pamphlets on street corners or sweeping the floor of a dusty communist bookshop: Where can one find in Deleuze the kind of subject-half bored, half distracted, neither entirely in the present or the future-who nevertheless dutifully sets up chairs for a political event held in the basement of an old church? Depersonalized? Pre-individual? Post-Cartesian? Certainly, but this subject is nevertheless very difficult to phrase in the language of the nomad or schizo. Is this a subject of knowledge or thought, of opinion or chaos? Todd May writes that "Deleuze throws in his lot with the nomads, with those whose restlessness sends them on strange adventures, even when those adventures happen in a single place, as they do for writers and philosophers" (2005: 149). It is the reliance of this political imaginary on the givenness of the strange (adventure) that worries me, but also the speed with which it jumps from the nomad to the philosopher, and from the schizo to the (always modernist, vanguard) artist. To get at the heart of the problem here we need to open up again an old political discussion around the relationship between means and ends, but also to openly advocate for the necessity of Ends themselves as the basic constitutive unit of the political.

Though they are often not separated by Deleuze himself, there are three ways in which the concept of becoming appears in his work. Becoming, for Deleuze, is a) an ontology, b) a figure of political possibility, and c) an ethical comportment (a relationship between the "self" and its limits). In its first form it is differential ontology, a name for things in the most general possible sense; in the second, it is a political strategy, a way of subtracting the virtual from capture by the sovereignty of the actual; and in its third form it is self-difference, the injunction to not fall prey to the obviousness of opinion and the passive aggressive comforts of routine. Far too often these various levels are confused in the discourse on Deleuze, a fact which masks the way in which these meanings enter into direct (and sometimes irresolvable) tension with each other.

Why? Because we do not yet know if becoming is a means or an end and whether becoming, construed as means or as its own end, does not openly negate itself. Ian Buchanan is right: you can find a program in Deleuze (Buchanan 2000: 197). I would double down on this point and expand it: Deleuze should be actively transformed into a program, transformed indeed into the grandeur and specificity of an actual political Plan. But what if the Deleuzian End-a New Earth in his parlance, transnational socialism in mine-could only be brought into being by non-Deleuzian means. This disconnect-between means and ends-is one that deeply offends a poststructuralist doxa grounded in the political efficacy of difference itself. That something should emerge out of its opposite is certainly counterintuitive, but we should keep in mind that this was precisely the critical gesture at the heart of Nietzschean genealogy! In the 
continuing obsession with a homology between means and ends, difference as a strategy and difference as a goal, we can discern the old residues of religion-a world in which each element takes up its dutiful place in an orderly whole and in which things can only be (in appearance) what they are (in essence). "Deleuze's most utopian idea, but not his only one, is that one can think differently" (Buchanan 2000: 117). This is exactly right. But insisting on the capacity of the human to think differently, and even safeguarding philosophically or practically the capacity of thought to differ from itself, is not the same thing as laying down the conditions for a world (utopia itself) in which that capacity is institutionally enshrined (to say nothing of a world in which people are adequately clothed, fed, schooled, respected, etc.). Which is only to say that thinking otherwise-a thought that always risks lapsing into the sameness of an empty formalism-might itself be a barrier to the construction of a society in which thinking otherwise as such is finally the rule and not the exception.

\section{References}

Barthes, Roland (2005). The Neutral. New York: Columbia University Press.

Buchanan, Ian (2000). Deleuzism: A Metacommentary. Durham, NC: Duke University Press.

Buchanan, Ian, and Nicholas Thoburn (2008). Deleuze and Politics. Edinburgh: Edinburgh University Press.

Colebrook, Claire (2006). Deleuze: A Guide for the Perplexed. London: Continuum.

Culp, Andrew (2016). Dark Deleuze. Minneapolis: University of Minnesota Press.

Dean, Jodi (2016). Crowds and Party. London: Verso.

DeLanda, Manuel (2008). “Deleuze, Materialism and Politics.” In Deleuze and Politics, eds. Ian Buchanan and Nicholas Thoburn, 160-78. Edinburgh: University of Edinburgh Press.

Derrida, Jacques (1982). Margins of Philosophy. Chicago: University of Chicago Press.

Derrida, Jacques (2004). Dissemination. London: Continuum.

Deleuze, Gilles (1986). Cinema 1: The Movement Image. Minneapolis: University of Minnesota Press.

Deleuze, Gilles (1994). Difference and Repetition. New York: Columbia University Press. Deleuze, Gilles. (1998). Spinoza: Practical Philosophy. San Francisco: City Lights Books. Deleuze, Gilles (2006). Nietzsche and Philosophy. New York: Columbia University Press. Deleuze, Gilles, and Felix Guattari (1987). A Thousand Plateaus. Capitalism and Schizophrenia. Minneapolis: University of Minnesota Press.

Deleuze, Gilles, and Felix Guattari (1994). What is Philosophy? New York: Columbia University Press.

Deleuze, Gilles, and Claire Parnet (2006). Dialogues II. New York: The Athlone Press.

Lundy, Craig (2012). History and Becoming: Deleuze's Philosophy of Creativity. Edinburgh: Edinburgh University Press. 


\section{Andrew Pendakis}

May, Todd (2005). Gilles Deleuze: An Introduction. Cambridge: Cambridge University Press.

Nancy, Jean Luc (1991). The Inoperative Community. Minneapolis: University of Minnesota Press.

Pendakis, Andrew (2014). "Politics in the Wake of Actually Existing Zeal: Badiou, Bosteels, and the Question of Political Affect.” Politics and Culture. Edition: The Politics of Alain Badiou. https://politicsandculture.org/2014/09/01/politics-inthe-wake-of-actually-existing-zeal-badiou-bosteels-and-the-question-of-political-affect/

Pendakis, Andrew (2017). “Dialectics of the Swing (Voter): Notes on the Formation of the Radical Centre.” Brock Review. 13.1: 54-70.

Robespierre, Maximilien, Jean Ducange, John Howe, and Slavoj Žižek (2007). Virtue and Terror. London: Verso.

Samuelson, Paul (2008). “The Dynamic Moving Center.” Spiegel Online. http://www. spiegel.de/international/world/paul-samualson-the-dynamic-moving-centrea-590034.html 